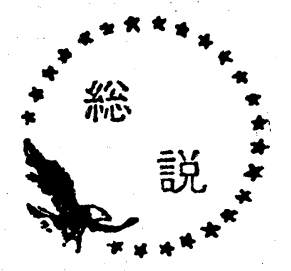

製 鉄 技術の将来の動 向

一昭和 49 年 10 月 16 日大会講演一

日本鋼管(株)技術研究所副所長 鈴 木 驍 一

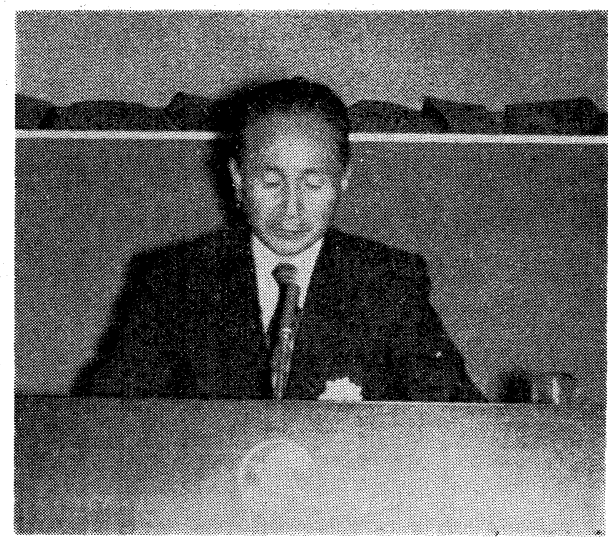

\section{1. 緒 言}

我が国は今日，生産量において米・ソと並ぶ世界の 三大製鉄国である。原料㞸の $84 \% ，$ 鉄鈗石の $99 \%$ を海 外に依存しながら，独特の臨海製鉄方式を確立し長期 契約による原料の共同購入，新規原料資源の大規模開 発の促進，大型専用船によるフレートの合理化をべー スとして世界中から使い易い原料を安価に購大し, 更 に次々と新鋭製鉄所を建設して，最新の技術を導入適 用し，充分な国際競争力を確立してきた。特に高炉関 係においては，大能力の圧延設備と熔銑主体の転炉製 鋼法に対応し，また，各社のシェア一競争もあって， 出来るだけ大量の熔銑を安定して供給することが要請 された。特に新しい高炉の建設に当っては，その時点 で可能な最大生産能力が至上命令となったので, 大型 化は急速に進んで, 今日 1 万 $\mathrm{t} /$ 日の高炉も実現し, 生産性, コークス比に执いて世界の最高水準にある。

しかしながら，この鉄鋼生産の急速な伸長に対し， 諸般の事情から原料岸の供給が不足気味であり, 最近 では世界的なエネルギー事情の悪化がこれに拍車をか けて楽観を許さぬ状況にある。また，公害問題もク口 一ズアッブされ，特に新立地の制約は先進国において 厳しさを増しつつある。今後10年間に世界の鉄鋼需要 は， 7.5 億から 11.5 億に増加すると予想されている が，そのうちのかなりの部分が発展途上国における需
要增である。原料炭や公害問題等の制約から, 先進国 の輸出余力があまり期待出来ない状況にある一方, 発 展途上国のナショナリズムは旺盛で自国鉄鋼業推進の 意欲が強く, 鉄鋼の生産は世界各地域に分散して行く 方向にあり, ローカルな立地条件や需要規模に応じ て, 必ずしも高転炉方式ではない種々の生産方式が実 施される傾向にある。以下これ等の技術動向について 概要を述べたい。

\section{2. 高炉における燃料消費量の節減}

\section{2-1 燃料比低減のための技術}

現在は勿論のこと, かなり将来に亘って製鉄の主流 は高転炉方式であり, 生産性, コスト, 作業の安定等 いずれを取ってもその優位は動かないと思われるが, この方式の存立基盤は優良な高炉用コークスであり, その動向如何では, 製鉄方式が大きく転換する可能性 も考えられる。コークス費用は, 熔銑原価占める比 率も高く，また技術的に大幅な原単位改善を計れる殆 んど唯一の因子であり, また, 高炉の生産性もコーク ス比あるいはこれに吹込燃料を加算した燃料比に反比 例する関係にあるので特に我が国のように, 燃料コス トの高い所では, その低減は以前から高炉に㧍ける最 大関心事であった。前述したような原料岸の供給不足 あるいは価格上昇が予想されるのに対しても，コーク ス比低下は, 将来に亘る非常に大きな問題である。

図1に，高炉ブロセスの概念を示した。図中アンダ ーラインは, 炉内で行なわれる主な反応および挙動を 示したが, 羽口先において，熱風によるコークスの燃 焼が行なわれて高温の還元ガスが発生し，これは炉内 の良好な通気性により, 逐次均一飞搪散しながら上昇 して炬頂から排出される。装入物は, 通常鉱石類およ びコークスに分けて交互に炉頂から投入され, 分配器 により, また, 固有の堆積角に従って円周方向均一な 層状に分布される。装入物は羽口先のコークスの燃焼 や鈗石類の還元熔解による体積減少に徉って逐次下降 し，この間上昇ガスとの間に，熱交換，還元，スラグ 生成, 軟化溶解滴下が行なわれる。このような反応系 において, 燃料コストの合理化を行なう方向として 


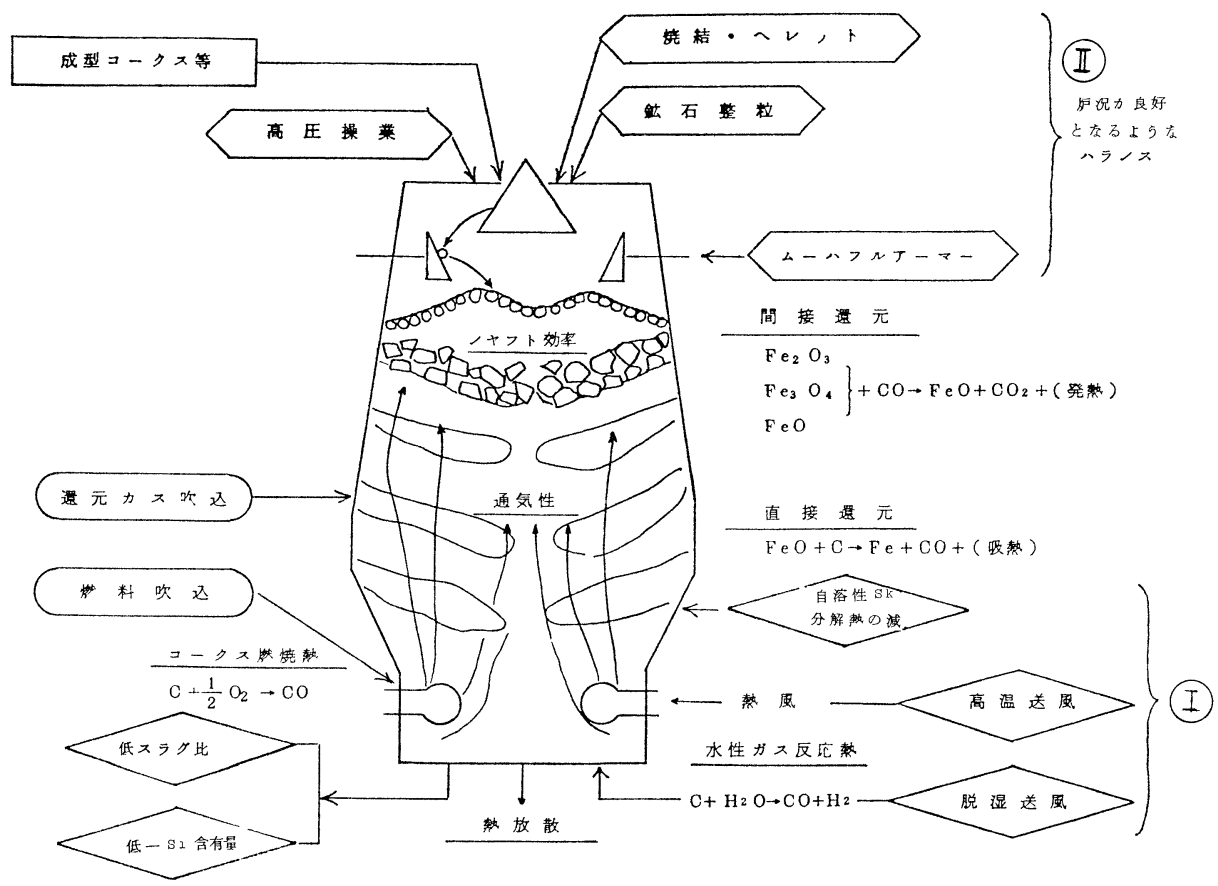

図 1 高炉の原理と燃料比低隇対策

は，次のようなものがある。

(1) 入熱増, 出熱减に対する対策 (図中 $<>$ で示 した。)

（2）ガス利用率を向上させる対策（図中 $\square$ で示 した。)

（3）コークスを代替燃料で置換（図中（二）で示し た。)

(4) 強粘結岸を一般炭で置換（図中 $\square$ で示し た。)

第 1 の入熱増に対しては，送風温度の上昇が行なわ れた。高炉では，炬頂ガスの替熱を熱風炬による送風 の予熱で回収しているが, 送風温度の $100^{\circ} \mathrm{C}$ 上昇に対 して然料比約 $15 \mathrm{~kg}$ 低下となる。

また，出熱减対策としては，高品位鉱の選択による スラグ比の减少, 自熔性燒結による石灰石分解熱の減 少。特に夏季において塩化リチウムによる脱湿装置を 使用し送風中湿分を調整することによる，羽口先での $\mathrm{H}_{2} \mathrm{O}+\mathrm{C} \rightarrow \mathrm{H}_{2}+\mathrm{CO}$ 反応の吸熱减少。低 $\mathrm{S}_{1}$ 操業によ る還元所要熱および熔銑顕熱の减少等種々の対策が実 施された。大型高炬の実現により, 熔銑 $\mathrm{t}$ 当りの熱放 散减少も寄与するところが大きい。第 2 のガス利用率 の向上対策については, 瓦斯, 固体の炉内にお抢举 動と反応の条件が複雑にからみ合っており，古くから
各種の測定装置を工夫して炉内の温度，ガス組成の分 布測定が行なわれ，最近ではこれ等の知見を綜合した 理論的な解析が行なわれ，高炉炉内の反応モデルが提 案され具体的な対策の指針として活用されている。炉 内の主反応は図 1 亿示されるような還元反応であり， その中で羽口先で生成した高温還元ガスが鉱石を還元 して， $\mathrm{CO} \rightarrow \mathrm{CO}_{2}$ になるのが発熱反応で，間接還元と いわれる。ところがこの反応は，高炉シャフト部各段 階での温度とガス組織に応じた平衡值があり，通常は 平衡をでも達せずに鉱石のかなりの部分が $\mathrm{FeO}$ の形 で高塭帯に降下してしまうことが多い。 $1,000^{\circ} \mathrm{C}$ 以上 の領域で過鄱の $\mathrm{C}$ の存在下では, 周知のように $\mathrm{CO}_{2}$ $+\mathrm{C} \rightarrow \mathrm{CO}$ となり, 結局還元反応は, $\mathrm{FeO}+\mathrm{C} \rightarrow \mathrm{Fe}+$ $\mathrm{CO}$ 飞外ならす，これは吸熱反応で直接還元と称せら れる。従って燃料比を低下させる眼目は鉱石を出来る だ間接還元し，ガスをその平衡值まで利用すること であり，温度分布，滞留時間，鉱石分布とガス分布の バランス，鉱石の被還元性等が要因となるが，具体的 な対策としてます鉱石の $10 \sim 25 \mathrm{~m} / \mathrm{m}$ 整粒および還元 性のよい焼結,ペレノトの多用が 戦後急速に普及し た。高炉炉内を別の見方からすると巨大な充塡塔であ る。この中でガス利用率を向上させるためには，充填 物と上昇ガスとの接触効率を最適化することが重要で 
あるが，一方後述するように生産性の面では極力多量 のガスを炉内に円滑に通過させるよう，それに適した ガス分布のパターンが重要であり，これ等の目的のた めに両者の最も良いバランスを維持することが求めら れる。このため装大物の整粒，特に微粉の除去が行な われ，また，炉内での粉化を極力少なくするように䒾 入物の泠間, 熱間の性状改善が行なわれて来た。特に コークスの役割は重要で羽口先で燃焼を開始する迄, ほとんど性状が変化せす装入物の軟化融着が起る高温 域での通気性の維持に大きな寄与をするものと考えら れており，その性状は，高炉炬况の維持汇影響すると ころが大きい。原料中の微粉や, 亜鉛, アルカリ等の 不純物の存在も重要な問題である。高温部で揮発した 覀鉛，アルカリ等は，温度低下により一定のゾーンに 沈着し，また上昇ガスに運はれる微粉も，流通の変化 により，一定位置に集積されることもあり，状况によ っては, これらは炉壁に強固に付着成長し, 通気性を 大きく変化させる。これらの現象を早期炕発見予防 し，あるいは発生を確認したならは爆破除去すること
も行なわれている。大型高炉に打いては，炉径の増大 に伴って分布の不均一が起りやすいことは常識的に想 像されるところであり, 事実図 2 亿示すよらなシャフ 卜効率 ${ }^{1}$ （シャフト部でガスが平衡值まで利用された 状応の指標となる。）の低下傾向がある。この対策と して，ムーバフルアーマーと称し，炉口金物を可変に して径または角度を変え, 装入物の落下点を変化させ て分布を調整することが行なわれている。経験的とム 一バブルアーマーの作動は, 炉㑆の変化伩して非常 にきつい影響を及ぼすことが確認され，随って上手に 活用するとよい分布を確保することが出来る。また， 高圧操業も有糼であり, 図 2 のように超大型高炉をこ れらの対策により中小炬と変わらない勃率が得られて いる現状である。このようにシャフト効率の維持向上 には，原料処理，操業の各種対策上，細心の注眷が払 われており，各種の計測手段の適用および測定結果の 操業へのフィードバ，クが害用化されつつあるが，現 状は実績が先行しており，理論的な面では，また今後 の解明に待つところが多い。

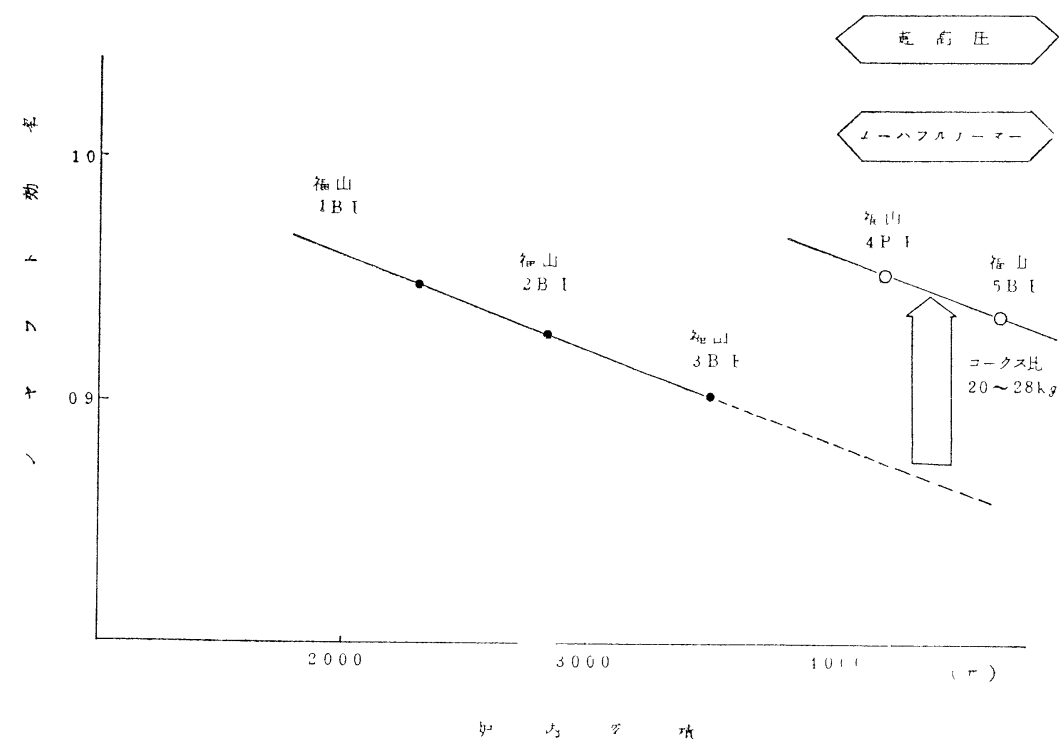

図 2 大型高炉における分布改善の必要性

\section{2-2 コークスを他の燃料で置換する技術}

\section{2-2-1 酸素フ化を利用した重伷の多量吹込}

燃料コスト低下のため, 次に実施された方法は, 複 合送風即ち羽口から燃料を吹込んでコークスと置換さ せる技術で，我が国では昭和36年以来実施され，最近 では特に酸素つ化を併用して発展している。吹込燃料
は, 重伷, タール2), あるいは微粉孷3) 使用されて いる。羽口加ら重伷を吹込む場合, 送風温度, 送風中 の湿分, 酸素フ化率を考慮した高炉の安定操業領域か 存在する。炉頂から装入されたコークスが約 $1,400^{\circ} \mathrm{C}$ に予熱されて来るのに対して，吹込まれる重伷の愠展

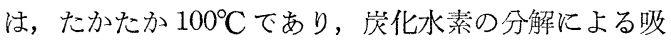




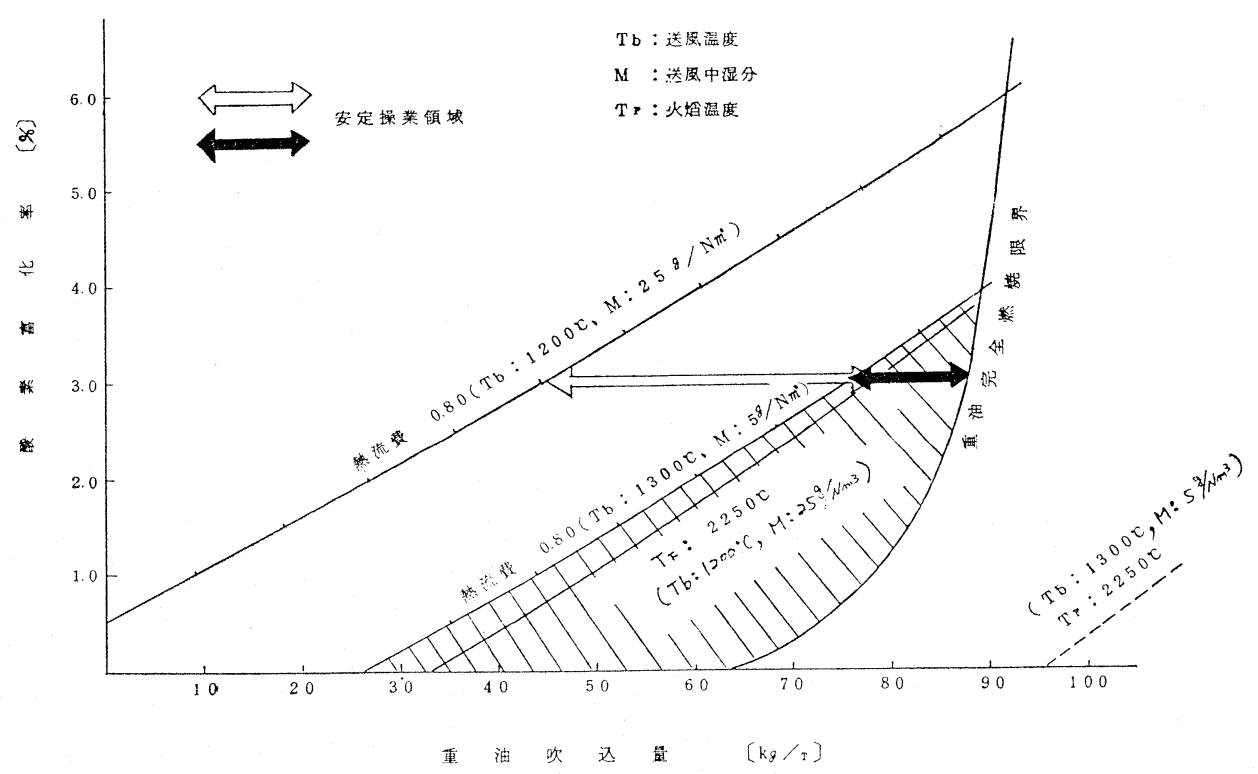

図 3 高温送風, 防湿, 酸素富化, 重油吹込みを考虑した高炉の安定操業領域

熱もあるので羽口先の温度水準を維持するためには, 何等かの熱補償が必要である。送風温度上昇, 送風中 湿分の減少の外, 酸素フ化により発生ガス総量を減少 させ火焰温度を上昇させることが有効で，図 3 亿理論 火焰温度 $2,250^{\circ} \mathrm{C}$ 以上之仮定した場合の限界を，送風

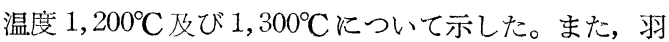
口を燃焼バーナー之考えると, 重油の燃焼には一定の 過剩酸素比が必要であり，これ以下では煤の生成によ り種々のトラブルが発生する。この煤を生成しない燃 焼限界は酸素フ化率によっても変わり，同じく図 3 に 示されている。一方酸素フ化により火焰温度は維持出 来るが, $\mathrm{N}_{2}$ 減少により熱風䫓熱の入熱が減り,シャフ 卜温度が低下して装入物の予熱不足 ${ }^{4}$, 直接還元の増 加 $4^{4)}$ 来す。酸素フ化によりコークスと燃料を置換す る場合, 置換率 1.0 即ちトータル燃料比が変わらない

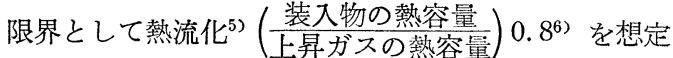
し, 図 3 に示した。図 3 は, 日本鋼管の試験高炉での 高酸素つ化操業の実験(4)をもとにして，実際高炉に適 用しうる理論を確立し, 当社福山高炉の重油吹这時の 安定操業域を推定したものである。上述した 3 つの限 界条件加ら，送風温度 $1,200^{\circ} \mathrm{C}$, 湿分 $25 \mathrm{~g} / \mathrm{Nm}^{3}$ 亿打

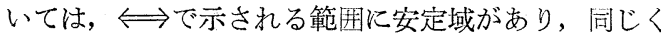
$1,300^{\circ} \mathrm{C}, 5 \mathrm{~g} / \mathrm{Nm}^{3}$ においては火焰温度の条件满た されるので, 他の 2 条件, 即ち重油の煤を生成しない 然燒と，熱流比で規制18)される がある。何れにしても, 羽口からの重油吹込は，たと
え酸素フ化をしても $70 \mathrm{~kg}$ 位から急速に安定域がせま くなり，この面から吹込量には限界がある。

2-2-2 還元ガス吹込み技術9 10) 亿対する期待

羽口先で, コークスや重油の燃焼により還元ガスを 発生し，これが滈炉の熱源及び還元刘の役割を担うこ とは前述した通りであるが，その一部を炉外で変成し た還元ガスで代替し, 高温 $\left(1,000 \sim 1,200^{\circ} \mathrm{C}\right)$ で同じ 温度域のシャフト下部に吹込みを行なうと、コークス 比は炉下部熱収支から必要とされる計算值約 $200 \mathrm{~kg}^{11}$ に近づけることが可能である。日本鋼管の試験高炬に おいて，重油を酸素で部分酸化した還元 ガスを使用 し，図4亿示すような実験結果9)を得をが，コークス 比は $570 \mathrm{~kg}$ から $360 \mathrm{~kg}$ まで低下し, 㯰換摔は, 重 油換算で羽口吹込の 1.0 亿対し, 稍低いが 0.8 であっ た。コークス比の低減に応じて, 羽口先での発生ガス 量が減少するので, 最も問題になる炉下部の通気性が 改善され，生産性が著しく向上する可能性がある。ま た，炉況の調整に対しても装大物の降下を抑制しなが ら筒温還元ガスの増量が出来ることは非常に魅力的で

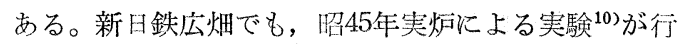
なわ机実用の可能性が碓認された。しかしながら, 問 題はいかにして安い還元ガスを得るかである。羽口先 で発生する還元ガスに比べ，少なくも安いコストでな ければならないが，酸素による重油の部分酸化やナフ 少等の分解により得られるガスは, コスト的に不利で ある。日本鋼管では，炉頂排ガスを循環使用 ${ }^{12)} し ， そ$ 


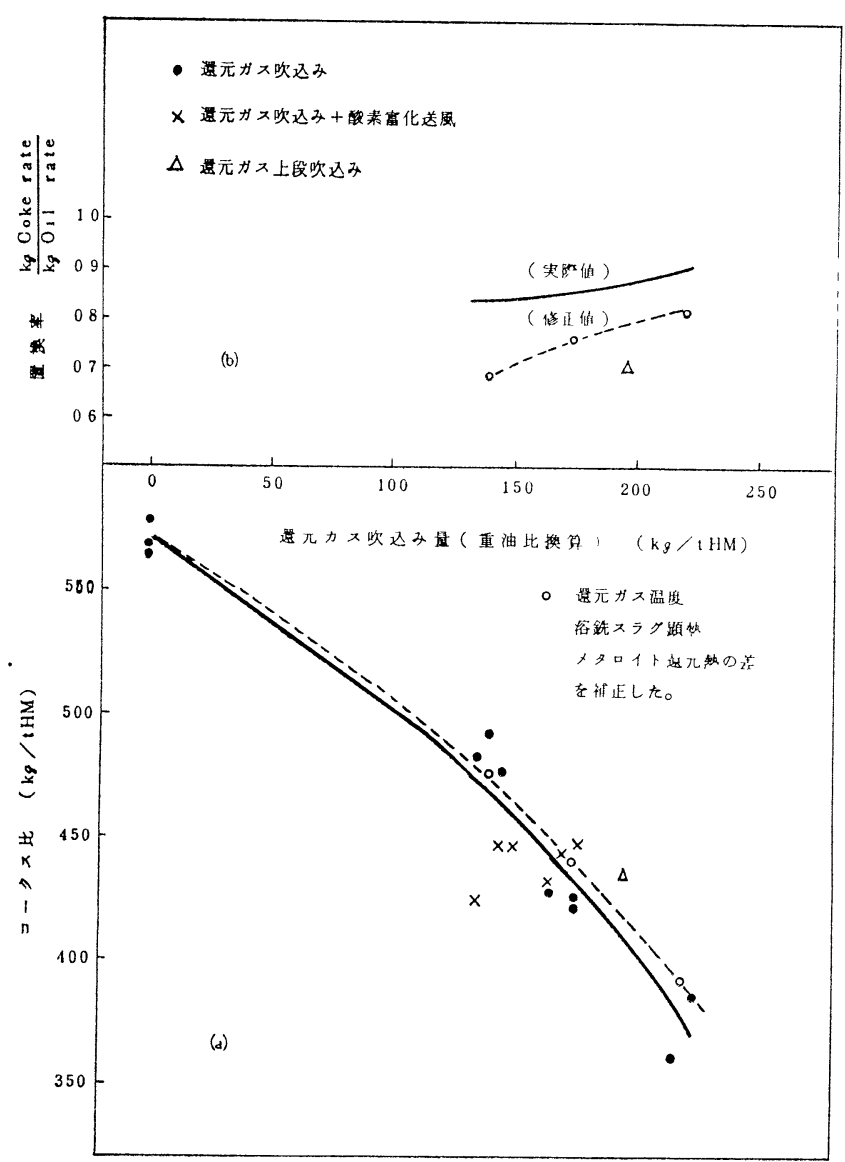

図 4 還元カス吹込みのコークス比（a）之置換率に対する効果（b)

の中に含まれる $\mathrm{CO}_{2}$ でコークス炉ガス中の炭化水素 を高温で吹込 み用の還元ガスに変成する方法を開発 し， $20,000 \mathrm{~m}^{3}$ /日 のパイロ,トプラントを建設して 10t/日 の試験高炉での実験 ${ }^{(1)}$ を完了した。 NKG プ ロセスと呼ぶこの方法は, 高炉, コークス炬の副生ガ スを利用して高価なコークスの大幅節約と生産性の向 上が達成される有力な方法であるが，この経済性は製 鉄所全体としてのエネルギーバランス ${ }^{13)}$ を考慮して検 討されなくてはならない，エネルギー危機以来，製鉄 所で使用する低硫黄然料の確保難と高価格が著しい今 日，これ等重油またはコークス炉ガスによるコークス 置換のメリ，トは，大幅に減退して了った。しかしな がら，なお情勢の変化あるいは低コスト天然ガスの大 手可能地域や，半成品主体の製鉄所等立地条件によっ て活用の可能性があり，注目に值する技術と思われ る。図 5 に, NKG ブロセスの概念を示した。一対の 蓄熱式変成器により, 加熱と変成を交互に行なうシス

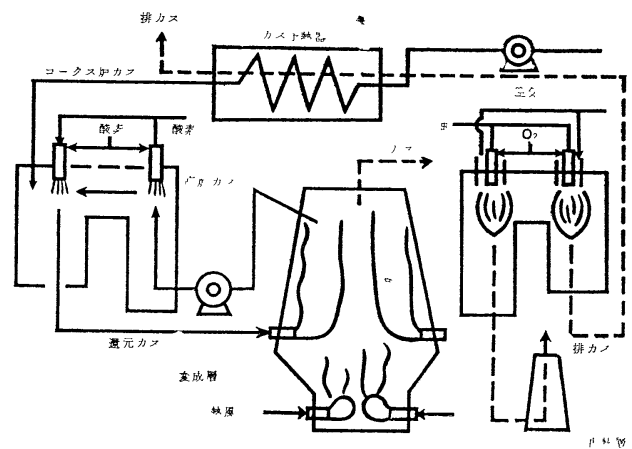

図 5 NKG プロセスの概念図

テムであるが，コークス炉ガスを煤の出ない限界温度 まで加熱し，高温に予熱した高炉ガスと急速に混合 し, 煤発生領域以上の温度で反応を完結させて, 2 次 的な加熱なしで高炉に吹込めることが特長である。

2-3 高炉コークス消費量節減の限界 ${ }^{14)}$ 


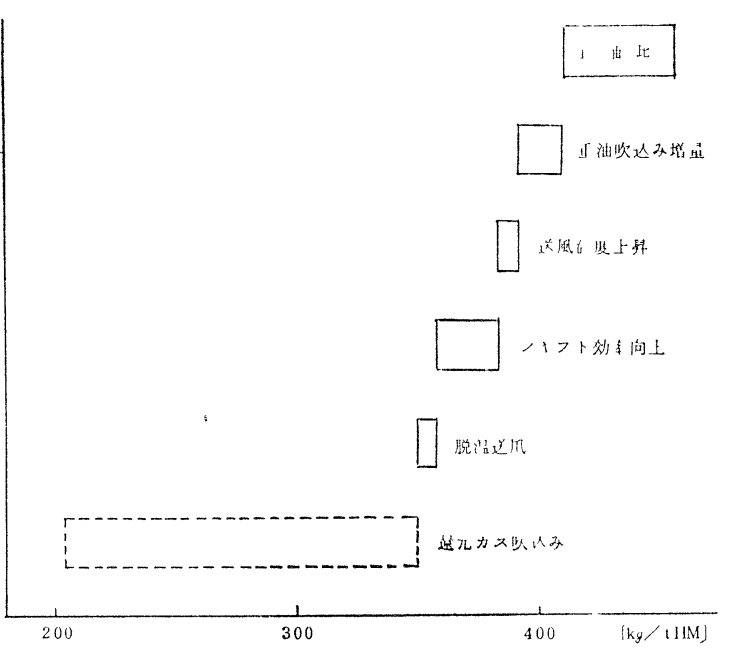

図 6 高炉コークス比低減の可能性と理想コークス比

以上述べたことのまとめとして，高炉の然料比また はコークス比の将来低下見込を検討して見ると次の通 りである。現状例えば当社の福山における平均值は図 6 に示すようにコークス比 $410 \mathrm{~kg}$, 重油比 $60 \mathrm{~kg}$ 合計 然料比で $470 \mathrm{~kg}$ であるが最大限に技術改善したとし て, 送風温度は熱風炉耐火物等の制約からが $1,300^{\circ} \mathrm{C}$ ほぼ限界であり，この場合重油吹込量は多少安全を見 て $80 \mathrm{~kg}$ が予想され, 酸素フ化率は $3 \%$ となる。シ ヤフト効率は 1.0 が理想状態であり, 送風中の湿分は 年中 $5 \mathrm{~g}$ に調整することは可能である。これ等の改
善による然料比の低下は図 6 に示す通りで，全部達 成された理想状態を仮定してもコークス比 $350 \mathrm{~kg}$, 重油比 $80 \mathrm{~kg}$, 合計燃料比 $430 \mathrm{~kg}$ であり, あまり 大幅な期待は出来ない。これ以上大幅なコークス比 低下技術としては, 還元ガスの吹込が最も期待され るものと言えよう。

\section{3. 高炉における生産性の動向}

図 7 亿わが国における燃料比, コークス比, 出 銑比の推移を示し，これ等の改善をもたらした対策 の主なむのを示した。昭 30 年頃より, 殆んど直線的 な操業成績の向上が見られるが, 各種の合理化対策 の他に，この10年間に 45 倍になった生産量の増加 が殆んど新鋭高炉の寄与によるものであり，その比 率の増加による向上がかなりのウェイトを占めてい る。従って上位高炉の操業成績について言えば，か なり以前から頭打ちになっているのが実状である。

出銑比といら面から高炉を眺めると，これは巨大な 充荟塔の中を，如何にして大量のガスを充填物の降下 を妨げることなく，また，熱交換還元効率が最適であ るようなパターンを保ちながら通過させるかという問 題である。装入物 は羽口先の燃焼空間に向って降下 し，降下に従って軟化融着が起り，更に熔鉄熔㓑とな って，コークス充揋層内を流下するいわゆる灌液充填 層に変化してゅく。上昇ガスは，層内の通風抵抗の分 布に従って断面で分布されるが，ガス量の増加，流速 の上昇飞伴って充坥層特有の部分的な流動, 吹抜け,

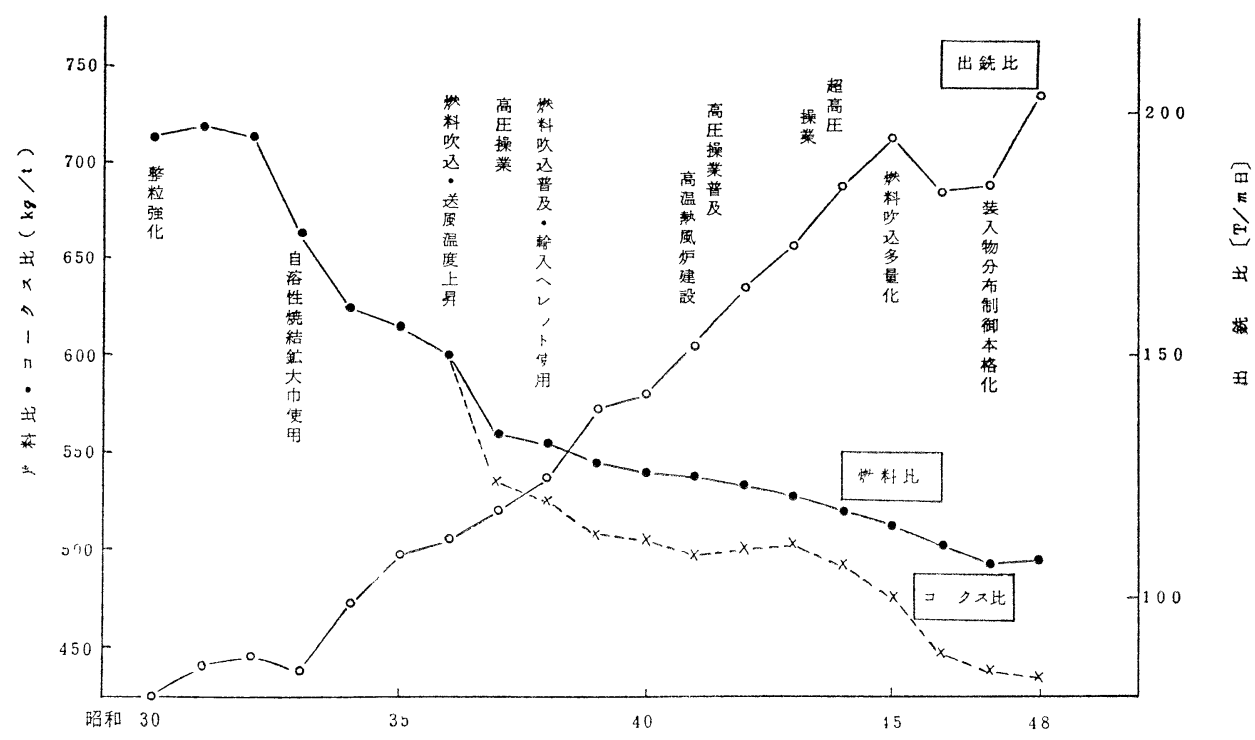

図 7 わが国の燃料比・コークス比及び出銑比推移 


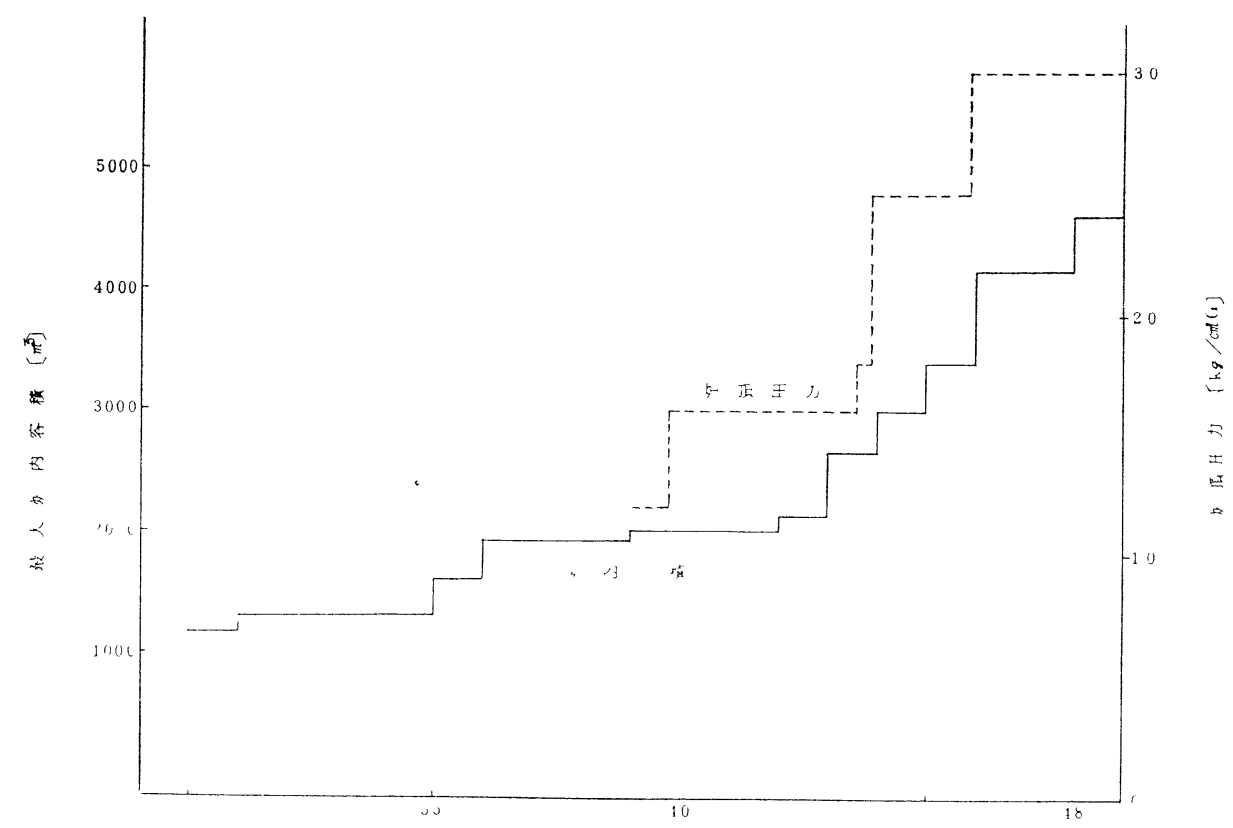

図 8 わか国における高炉の大型化と高圧化の傾向

融液の吹上け等の現象，あるいは前述した微粉や覀 鉛，アルカリの蓄積，炉壁への付着によるカス流の乱 れ等複雑な挙動があらわれる。これ等の啫現象を, 一 定のあるパターンで安定して維持することが, 高炉炉 况の保持安定と言われるものて，州銑比の向_Lにつな がるか，その目的のために通気性の向上，通気分布の 調整, 粘性物の性状の改善, ガス流速の抑制等が行わ れた。具体的には, 整粒, 高压操業, 装入物分布調 整, 䒾入物の冷間熱間の性状改善等てあり, また, 炉 内にゾンテを挿入して連続自動的に温度, ガス組成, 圧力の計則を行い，変化をチェクすることも大きな 前進を遂けている。

我が国では，高炉の大型化が急速に進んたか, 炉容 の桩大は圧損を考慮して炉高を増さす，炉径の増加に より行われた。炉内を通過するガス量は炉容積に比例 し, 炉容積は断面積に比例するのて, 同一の出銑比に おいては，炉の大小にかかわらす平均の空塔速度はほ ほ一定となる。しかしなから，10数的の炉床径におい て, 关風の吹込, コークスの然焼は周辺のみで行なわ れるのて, 笔生カスが上昇搪散する迄の炉下部におい ては, 有㕮ガス通路面積は炉周辺のト一ナッ状の区域 に限られ，炉床径の比例でしか増加しない。結果的に は, 下部炉周辺のガス流速は, 炉床径もしくは炉容積 の平方根に比例して増加する傾们にあることか推定さ れる。流速が限界を越すと前述したような種々の通風
障害を発生するのて，高圧操業を強化して 流速を抑 え，これに対処した。図 8 には，年度毎の新設高炉の 炉容積の増加と炉頂圧の上昇傾向を示している。現在 ては炉頂压は設備能力 $30 \mathrm{~kg} / \mathrm{cm}^{2}$, 笑際の操業時の 炉頂圧扩 $25 \mathrm{~kg} / \mathrm{cm}^{2}$ に達しており, 炉容積と操業 時炉頂圧の関係は出銑比 23 を維持するのに必要な理 㖮値とほぼ一致している。基本的には，これが高炉を 大型化し，しかも出銑比を維持向上せしめた理論的根 拠となっており，また，これらが実証されたため大型 化が急速は進んたと考えられる。今後, 䯩炉はどこま で大きくなるかといら問題に対しては，その経斉性か 検討されなくてはならない。

規模のメリ，トに対して, 必要な高圧操業による作 業費, 設備費の増加がデメリ，トに働いており，コス 卜的には図 9 に示すよらに $4,000 \sim 5,000 \mathrm{~m}^{3}$ 付近て 変曲点 ${ }^{15)}$ があると算定されている。コークス強度の低 下が心配されているが, 理論的には, 通風性の悪化に よる限界ガス流速の低下を出銑比减によるガス流速低 下て補償することになるのて, 炉の大小に拘らす减産 率は同してあろら。たたこの場合, 高压操業の強化て 出銑比をカバーする可能性があるのに刘して, 大型言 炉は現状でも作業性, 設備保安の面から高圧操業の限 界に近くなっており, 余裕が少ない。また, 炉况変動 の影響㙉が大きい。これ等, 経斉性及ひ操業上の制約 から, 今後は炉容積执大のテンポが鈍り, また, 出銑 


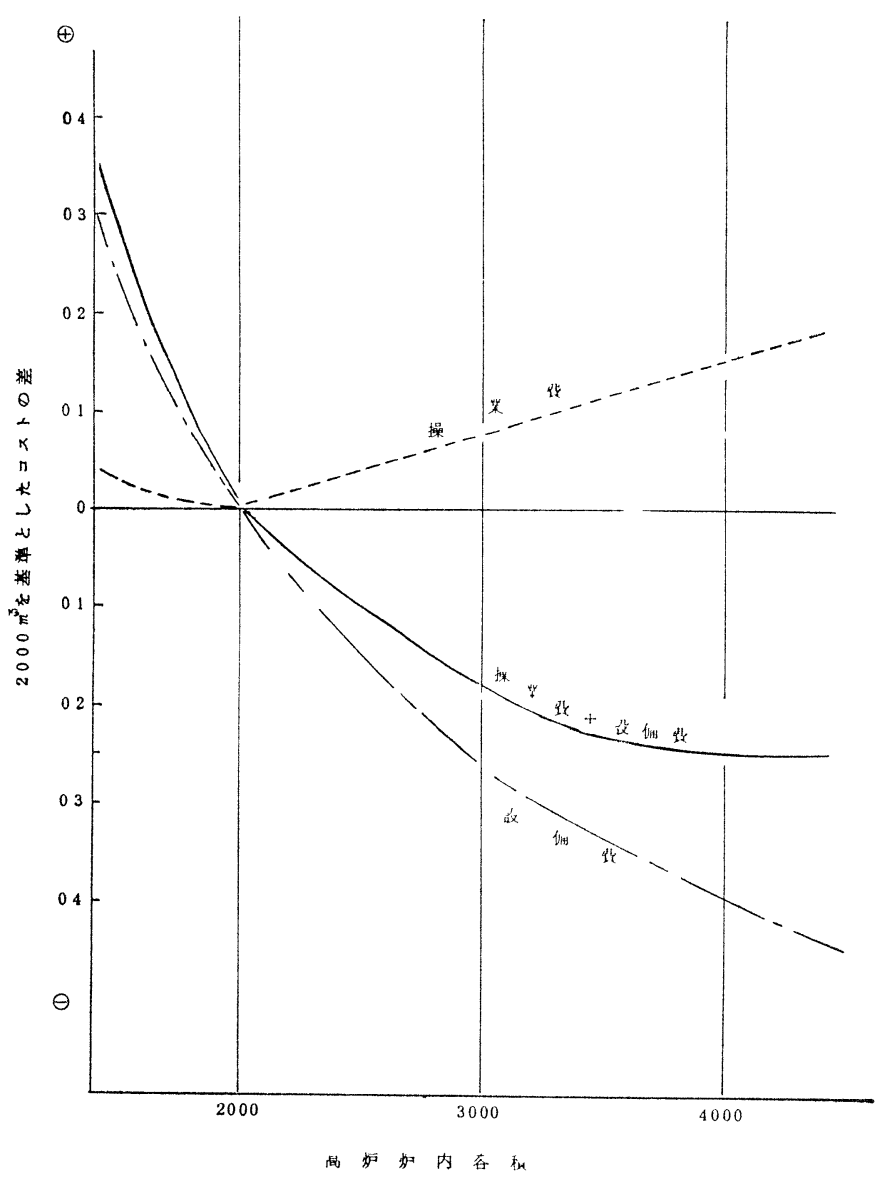

図 $92,000 \mathrm{~m}^{2}$ 級高炉を基準とした大型高炉の設備費と操業費の傾向

比も横這いか，むしろ新設高炉では計画值を低目にし て安定を狙う傾向になると思われるので，高炉 1 基の 生産量は，10,000 t/日 程度で頭打ちになってくるの ではあるまいか。しかしながら，大型高炉は将来と も, 我が国臨海製鉄所の中核てあり, 製鋼能力, 屑鉄 供給量とのバランス上, 出銑比の低下は許されす, 從 ってコークス性状の維持が今後第 1 亿重大な項目とし て検討される必要がある。

\section{4 コークス対策の動向}

我が国で使用しているコークス用の原料岸は米国, カナダ, 豪州および国内岸を主力として, その他多数 の銘柄を配合している。石崖の組織学的検討が発展し コークスの強度を支配する因子として, 石炭の岸化度 と流動度の概念 ${ }^{6)}$ が導入されたが, 配合炭として実用 されて来たのは，図10に示されるような限定された範 囲であり,この範囲内では, 炭化度, 流動度は, コー クスの強度と高度の相関がある。我が国の原料炭事情
特に炭化度の高い米国強粘炭と, 流動度の高い国内炭 の逼迫から, 近い将来これ等の指数が，この範囲を外 れて低下し，高炉用として必要なコークス強度の維持 が困難になる事態が心配されている。配合岸の中に， 予めバインダーを用いて成型した石炭のフリケノトを 倱合する方法を成型炭装入法と呼んでいるが，これに よれは，上記の範囲が拡大されることが確認され実炉 て操業されている。また，人造粘結炭を配合して配合 炭の流動度不足を補ってやることも有効であり，両者 を併用すれば，図中示した範囲まで，配合炭の限界を 拡大することが出来る。しかし，更に原料炭選択の自 由度を大きく拡大するためには，成型コークス法の実 用化にまたなくてはならない。これまでに成型コーク スは，小規模短期間の実炬試験の報告 ${ }^{17) 18319920)}$ は多数 発衣されているが，評価はまちまちである。製法によ っては，通常のコークスと比較して結合組織の差によ る高塭性状の差異が考えられ，また，形状比重の差に 


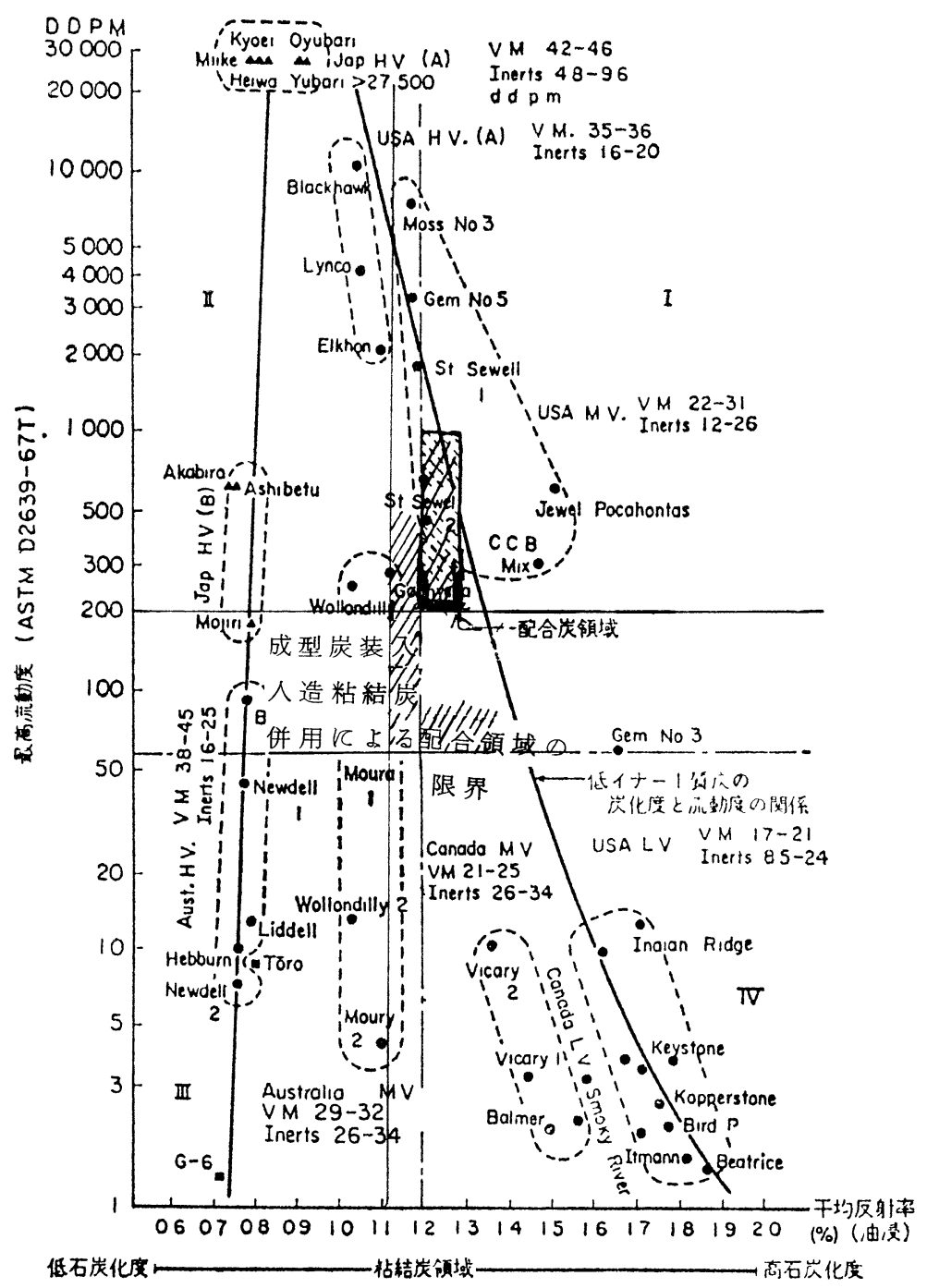

図 10 原料炭の最高流動度と反射率の関係 ( $\mathrm{VM}$ : 無水無灰ベース)

よる炉内分布の変化も影響するところが大きいと予想 される。実験室的には高温性状の解明が必要である が，やはり何といっても大型高炉の高稼働における実 炉試験が必要であり，現在までに，はっきりした結論 は得られていない。

米, 独, 英等, 成型コークス原料に適した石炭資源 を大量保有している所では研究は熱心に行なわれてい る。我が国では，未だ緒についたばかりであり，加え て成型コークス原料として量的に安定し，コスト的に も有利な供給源確保の可能性は少ない。また，新しい コークス炉が多く, 今後長期間の稼働が可能な状况に ある。従って，我が国では，コークス炉を使用し，成
型炭装大や人造粘結炭系の補助手段を併用しながら， 何とか上述した範囲の配合を維持してゆく購買努力が 最優先で行なわれるのであろう。成型コークス法への 転換はごく一部であり，乙かも出来れば在来のコーク ス炉を活用し得る方法が望ましい。何れにしても製造 方式, コストの検討等今後に待つ所が多く, 工業化の 前に情勢の見定めが必要であろう。

\section{5 高炉を用いない製鉄技術の動向 ${ }^{21)}$}

現在，工業化されている高炉によらない製鉄法とし ては, 天然ガスを改質し，これにより $\mathrm{CO}$ および $\mathrm{H}_{2}$ からなる還元ガスを製造して，鈗石のガス還元を行な い還元鉄を製造する方法があり，シャフト炉 166 万t/ 


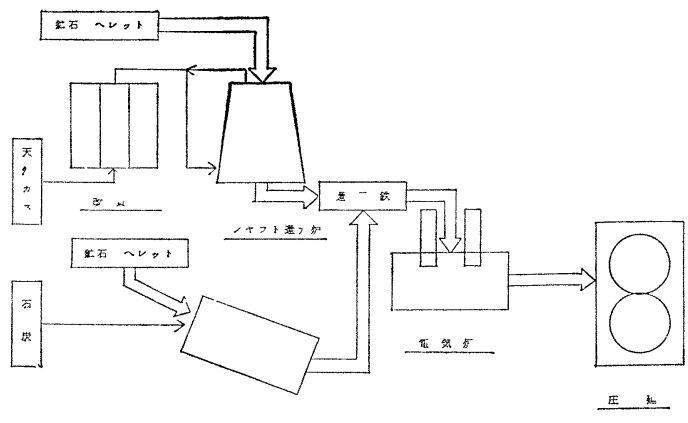

図 11 直接製鉄概念図

年, レトルト炉 135 万 $\mathrm{t} /$ 年, 流動層還元炉 100 万 $\mathrm{t} /$ 年 が生産されている。また，石岸を還元材とする ロータリーキルンによる還元も，145 万 t/年 程度行 なわれている。特にシャフト炉は近年急速に発展しつ つあり，話題となっている。図11にその概念図を示し た。成品は $90 \%$ 程度の還元鉄て, 電気炉により熔解精 鍊される。高転炉法に較べて小規模な生産方式であ り，1基当りの生産量は40 50万 $\mathrm{t} /$ 年 が実績である。 シャフト還元炉は，コークスを含まない充壃塔で，高 温で融着の発生しやすい条件にあり，また，還元鉄の 抽出が高炉における熔銑垶の抽出処理ほど簡単にはゆ かないことが大型化を困難にしており，スケールメリ ノトを得ることが難かしい。また，工ネルギ一特に電 気エネルギーの消費が多いことは図12に示す通りであ り，大規模な高転炉生産方式に比較して粗鋼段階でコ スト高である。今後の予想でも将来全世界でやっと $6 \%$ 程度 ${ }^{21)}$ がこれ等の方式で生産されるものと見られ ており, 先進国の主流にはなり得ない。我が国ではダ ストの有効利用のためにロータリーキルンによる直接 還元が各所で操業を開始しているが，このような特殊 な用途に限られるのではあるまいか。しかしながら，

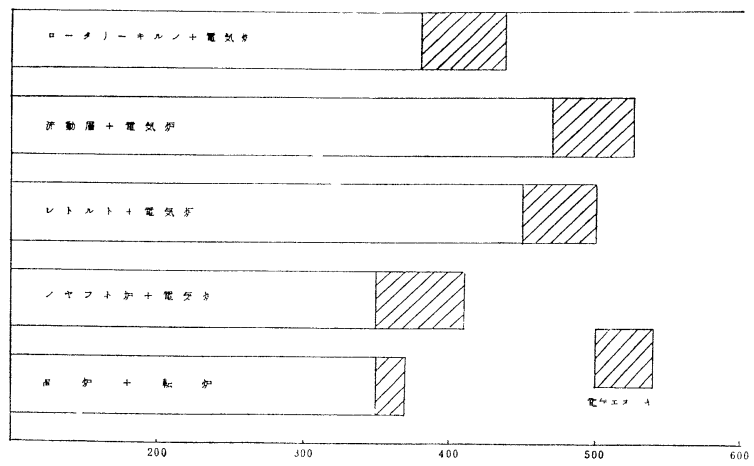

図 12 粗鋼トン当りエネルギー所要量 $\left(\times 10^{4} \mathrm{kcal}\right)$

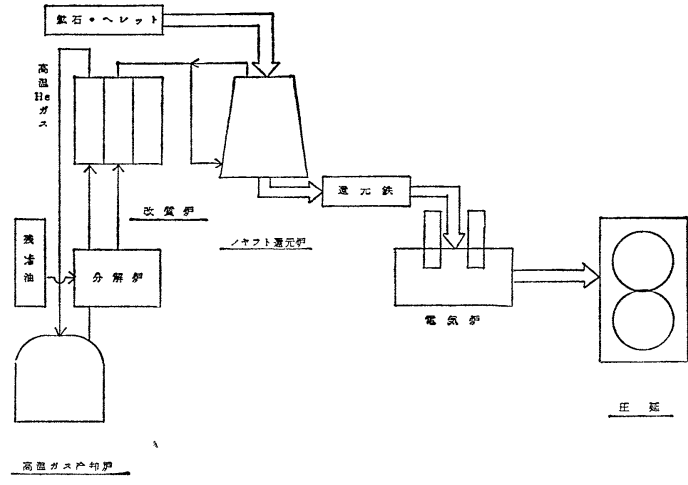

図 13 原子力製鉄概念図

これ等の方式は天然ガスや，還元用石炭，鉣石の安価 豊富な一部地域や, マーケ,トの小さい発展途上国の 過度的小規模生産に対しては, 高転炉方式と充分匹敵 し得る経斉性がある。先隹国における大規模製鉄所の 新立地の制約及び発展途上国のナショナリズム, 資源 の偏在等を考慮するとき, ある程度各地に分散した形 で発展するであろう。高転炉方式は, 従来大型化によ るスケールメリットの追究に終始して来たが，コーク ス炉，酸素設備等付帯設備の合理化を前提としてコン パクトな再編成も，充分可能性があり，また，コーク スの $50 \%$ は還元ガス吹込に置換することも出来るの で, 立地, 需要規模に応した再検討を是非行ならべき である。更にまた, 将未のエネルギー事情を考慮する と, 我が国では原子力の活用を充分考慮してゆくこと が必要である。高塭ガス冷却炉より得られる $1,000^{\circ} \mathrm{C}$ の核熱の利用により減圧残揸油等重質油を分解して高 温還元ガスを製造する方法は，我が国においても安価 な還元ガスの得られる見込みがあり, 将来のエネルギ 一対策の一つとして研究 ${ }^{22}$ が開始されている。図13に 概要のシステムを示したが, 熱交の耐熱材料, 還元ガ ス製造方法, 大型還元炉の開発等, サブシステム にも問題が山積している。今後長期に亘って，原 子炉の開発, 安全性やトータルシステム最適化 等, 研究が進められよらが, 一応の目標として, 1980 年には, $50 \mathrm{Mwt}$ の原子炉を中心とした実証 炉の稼働が予定されており, 最終的には水分解に よる $\mathrm{H}_{2}$ 還元の実用化も充分可能性として検討に 值するものである。

\section{6 結 言}

以上述べたよらに, 我が国では依然として臨海 製鉄所における大規模な高転炉法が主流の位置を 占めるであろう。生産性, 燃料比等は頭打ちとは 
いえ，大容量の炉を安定して稼働するための操業管 理, 設備保全, 計測手法や炉況予知手段の開発等, 今 後ますます発展され実施されるものと予想される。こ れに従って，原料炭選択の自由度拡大のための対策が 情勢に即応し，必要に応じて実施され，また，各種然 料の相効的に安価な入手が可能になれば，シャフトか らの還元ガス吹込みが行なわれるようになろら。これ 等大規模な製鉄所の存立, 新立地の障害に大きく影響 する公害問題については, 間もなく排水処理, 脱硫脱 硝等の対策も目途がつき，満足し得る段階に到達する ものと思われ，今後の鉄鋼需要増大に刘応して国内新 立地の見直しがされることも期待をしたい。

次の段階としては，原子力製鉄に進むであろう。こ れに適したシステムが研究されなくてはならないが， 還元ガスの温度が低いので，この段階で直接還元が対 象となってくる。

一方，発展途上国の新製鉄所計画も活発に企画実施 されようが，それぞれの資源，技術レベル，需要規模 に応じて高転炉方式，あるいは直接還元等各種方式が 選定されよう。従来, 専ら大型化のみを追究して来た 我が国であるが，これ等のプロジェクトへの寄与のた めには，直接還元方式のみでなく，高転炉方式も含め て，コンパクトな一貫製鉄方式の開発を見直すことが 必要になってくると思われる。

\section{文献}

1) A. Rist and N. Meysson : Rev. Metall, 17, (3), 121 (1964)

2) 千葉，里見：銑と鋼，50，(3)，104 (1964)

3）森永, 田島, 楠野, 城本, 金山, 松岡, 鉄と鋼, 52, (2), 107 (1966)

4）宮下, 大槻：鉄と鋼，57, (14), 2084 (1971)

5) B.I. Kitaev et al., "Heat Exchange in Shaft Furnaces (1967)”

6) J. Cochery : Rev. Metall, 21, (11), 945 (1967)
7) T. Miyashita, H. Nishio, T.Shimotsuma, T. Yamada, and M. Ohtsuki, Trans. ISIJ., 13, (1), 1 (1973)

8）樋口，飯塚，黑田，炭槞：鉄と鋼，60，(8), 1087 (1974)

9）宮下，西尾，下間，山田，大槻：鉄と鋼，58, (5), 52 (1972)

10）八塚，中山，大森，原，井口，鉄と鋼，58，(5), 68 (1972)

11) T. Miyashita, K. Sano, H. Nishio, S. Ohzeki, T. Nayuki, Ironmaking Canf. Proc. AIME, 33, 39 (1974)

12）西尾，宮下，鉄と鋼，59，(12)，1506 (1973)

13) T. Miyashita, K. Sano, H.Nishio, S. Ohzeki, T. Nayuki, L. Chaussy, Trans. ISIJ., 14, 177 (1974)

14) G. Suzuki, T. Kobayashi, T. Miyashita, Ironmaking Conf. Proc. AIME, 30, 499 (1971)

15) S. Yamashita, Report of Proc. IISI 6 th Annu. Conf. London, 90 (1972)

16）宮津，奥山，福山，杉村，日本鋼管技報， $52 ， 1$ (1971)

17) J. H. Strassburger, E. J. Ostrowski, J. R. Dietz : Journal of Metals, 295 (1962)

18) A.Poos, C. Vanosmael, N. Ponghis, Ironmaking Conf. Proc. AIME, 32, 448 (1973)

19) K. Sugasawa, K. Tasaka, Y.Sunami, H. Hino, C. Flockenhaus, Stahl u. Eisen, 93, (1), 24 (1973)

20）加瀬, 林, 柴田, 中川, 草野, 松井, 中村, 鉄と 鋼，60，(11)，18 (1974)

21) Battelle-Institut Annual Report, IV-1

22）三浦：燃料協会誌，53，(10), 822 (1974)

\title{
Tendency of Ironmaking Technology in Future
}

\author{
by Gyoichi Suzuki
}

(Nippon Kōkan Co.)

SYNOPSIS :- In Japan, the BF-BOF system at the large scale seaside plant will continue to occupy a main position of iron production in future. Both of the increase 
of productivity and the decrease of the fuel ratio reach the top, recently the activity for the shortage of good quality coking coal is to be the greatest problem for the iron making engineer.

However, some alternative methods for saving the amount of good quality coking coal are already put in operation in the commercial scale. Even the reducing gas injection into blast furnace stack will come into a commercial application if the energy condition is favorable. In near future, the application of nuclear heat to iron and steel making process will probably be considered.

On the other hand, the several projects for constructing integrated steel plants are going on in many underdeveloping countries. In such the countries, eithes $\mathrm{BF}-\mathrm{BOF}$ system or any direct reduction system is chosen according to their conditions of natural resources and market demands.

In Japan, we found out economic only to introduce large scale iron and steel making facilities, however, the development of high efficient small scale steel production systems has to be reconsidered to make any contribution to the industrialization of those countries through joining to their projects. 